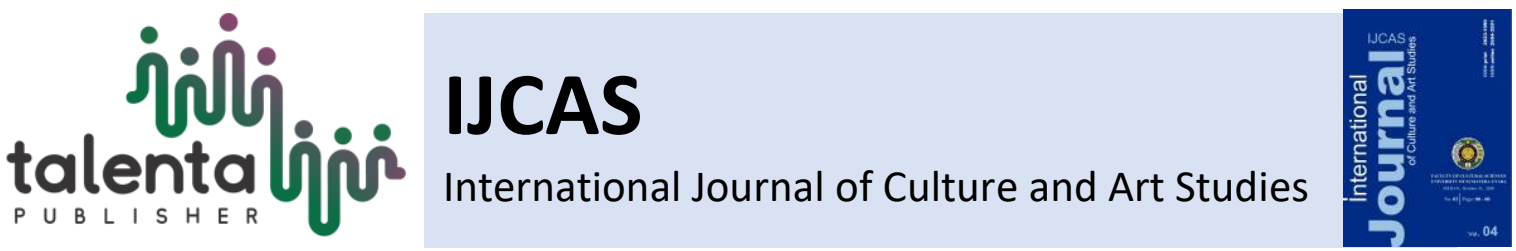

\title{
Art as Contextual Epistemology: A New Theoretical Perspective on Contemporary Avant-gardism in Africa
}

\author{
Clement Emeka Akpang \\ Department of Visual Arts and Technology, Cross River University of Technology CRUTECH, \\ Cross River State. Nigeria.
}

\begin{abstract}
Art constitutes a framework for the generation of new knowledge that enables a sophisticated understanding of society. It is deconstructivist/interrogative thus leads to the creation of alternative narratives and realities derived from complex visual interpretation of the universe, societies and circumstances. In a cognitivist sense, beyond aesthetic emotions/visual appeal art constitutes an intellectual source of knowledge through in-depth analysis of form, content and context of any given artwork. The paper adopts discourse and iconographic analysis as methodologies to introduce a new uncovered phenomenon of Contemporary Avant-gardism in postcolonial African art based on knowledge generation tailored to enforce change. This is achieved by interrogating the ideologies, methodologies and visual configurations of the works of contemporary African artists such as El Anatsui, Olu Amoda, Brett Murray, Kudzanai Chiurai, Clem Akpang and others. Their works instigate new lines of inquiries/knowledge through a renewed but subtle bohemian approach to artifactuality and interpretation of contemporary Africa. The paper submits that by its evocative/expressive nature, art creates structures of knowledge through subjective and visual dialogues that foster knowing in different ways beyond language. And that in contemporary African art-space this new artistic ethos is deployed as a form of avant-gardism that underpins the rationale of African art created in the continent today.
\end{abstract}

Keyword: Epistemology Alternative Realism, Avant-gardism, Contemporary Art, Africa, Epistemology Perspectives

Received 03 February 2020 | Revised 26 October 2020 | Accepted 28 October 2020

\section{Introduction}

Until the second half of the $20^{\text {th }}$ Century, traditional approaches to the conditions of scientific knowledge, that is the pursuit of certainty, remained the longstanding dominant ambition. Knowledge was conceptualised as the ability to provide warranted assertions based on evidence regarding the truth or falsity of discourse in which language is its representational vehicle. The idea that art could constitute a form of knowledge or its connections to epistemology was not widely considered.

However, since the inception of the $21^{\text {st }}$ Century, it is becoming clear that knowledge, understanding and ways of knowing are not only dependent or reducible to language and

\footnotetext{
*Corresponding author at: Department of Visual Arts and Technology, Cross River University of Technology CRUTECH, P.M.B 1123, Calabar, Cross River State, Nigeria.
} 
structures of written communication. As Michael Polanyi succinctly opines, "we know more than we can tell" [1]; what Polanyi alludes to is the fact that knowledge comes in different forms, and that the forms of its creation differ greatly. Thus, language and its systems are inadequate to fully convey all that is known accurately to transmit contextual meanings effectively. Even though this is the case, the systemic institutionalisation of scientific knowledge continues to alienate other forms of knowledge generation. As the French philosopher Michel Foucault argues, "the history of thought, of knowledge, of philosophy, of literature, seems to be seeking and discovering, more and more discontinuities, whereas history itself appears to be abandoning other irruptive events in favor of stable structures" [2]. What Foucault draws attention to is the abandonment of other forms of thoughts and ways of expressing/exposing knowledge/truth outside established structures. Foucault believes that in the irruption of new events, new possibilities of knowledge capable of providing sophisticated knowledge and understanding of cultures, societies, and ideologies can emerge.

These theories have contributed to the liberation of the term knowledge from dominance by the propositional in scientific terms, and such liberation is a critical philosophical advancement in contemporary scholarship. It is now possible to seek knowledge or ways of knowing from multiple sources by interrogating and applying structures that lie outside language and its propositional frameworks. This embrace of various possibilities of understanding is a new development that allows the revelation of more in-depth knowledge about the universe, concepts, and ideas.

Art is one of those possibilities that provides more profound revelation and unique visual parameters of knowing - it is a mechanism for the generation of knowledge, new forms of understanding, and an instrument for creating new alternative realities that further deconstruct the world around us. As a product of culture and society, art embodies societal value systems, philosophies, and cosmologies that can convey non-verbal ideas to onlookers. In contrast, as a conceptual/subjective tool, art conveys relative and individualistic interpretation of the universe, concepts, and ideas through interrogative visual dialogues that open philosophical windows into the artist's mind and thought processes. Art, therefore, is a potent tool for non-verbal communication and a non-scientific generation of knowledge capable of altering societal notions.

This paper is thus focused on interrogating this epistemological framework in artistic expressionism with particular reference to contemporary African art as its main objective. It examines the underlying ideas, especially the desire to create and communicate new knowledge that inspires many African artists today. Finally, the paper examines how diverse inspirations coalesce into a unified artistic voice that draws viewers' attention to societal circumstances and challenges in Africa through complex and sometimes literal visual dialogues. 


\section{Method}

\subsection{Iconographical Analysis}

Iconography is the description, classification, and interpretation of the subject matter of a work of art. It is derived from the Greek words eikon, meaning image or icon, and graphia, meaning description, writing, or sketch. Its primary purpose is to understand and explicate the meaning behind what is represented. It involves the definition, classification or analysis of meaning or symbolism in the visual arts that take into account the tradition of pictorial motifs and their historical, cultural, and social meaning. Advanced in modern scholarship by Erwin Panofsky in 1939, iconographical analysis is used to deconstruct artworks to reveal their inner meanings. It enables the description of the factual (or expressional), understanding of the subject matter derived only from a familiarity with and knowledge of the themes and concepts represented and an intrinsic interrogation of meaning or content, constituting the world of symbolical values. Such deeper meanings are derived from the interrogation of form, written text, and understanding of semiotics [3]. This analytical tool is drawn upon to deconstruct referenced artworks in order to expose their hidden meanings and construct a discourse consistent in the works of many postcolonial African artists that revolve around knowledge generation and dissemination to tackle the problems of the African continent today.

\section{$3 \quad$ Art, Knowledge, and Knowing}

Art is the most dynamic and multifaceted field in the humanities, which defies a unified definition. However, for this paper, reference is made to the description provided by the philosopher Eugene Kleinbauer. In his widely read book 'Modern Perspectives in Western Art History 1971' Kleinbauer describes art as the stylistic manipulation of any chosen media to express one's emotions, feelings, and thought processes, or to interrogate an idea/concept to reveal a subjective interpretation of reality and the universe. He goes further to define art as the production of a body of knowledge, most often using a set of technical skills, then concludes that art is a symbolic, immortal, and visual documentation of society [4]. What Kleinbauer's definition provides is an understanding that although art deals with aesthetic concerns, it also constitutes a compelling framework for knowing, expression, and exposition. Art, therefore, extends beyond the realm of technical/creative dexterity to an intellectual realm as a window into the artist's mind and his subjective revelations. Three variables from Kleinbauer's definition are crucial to understanding art as a mechanism for knowing - firstly, art interrogates, secondly it leads to the production of knowledge and thirdly, art is a reflection of society. In this sense, through the codification of meaning in visual form, art becomes an instigator of new ideas and perspectives through the creative interrogation and conceptualisation of ideas. Thus, the nature of art is not so much to aesthetically amuse or appeal, but to evoke [5]. 
Through its evocative nature, psychologically speaking, art transports us to another part of the world by providing deeper meanings/understanding to otherwise mundane realities to instigate new thought processes. The works of great masters such as Leonardo da Vinci, Pablo Picasso, and Salvador Dali authenticates this theory. Through visionary drawings during the apotheosis of the 15th Century Italian Renaissance many years before the industrial revolution, Leonardo da Vinci was able to provide accurate knowledge about babies positioning in the womb, and possibilities of metals flying in the sky and gliding on the water - his ideas paved the way for the invention of ships and airplanes. Through da Vinci's art, the possibilities of navigating the air, faster transportation, and the then mystery of babies' placement in the womb were demystified hence made vividly known. On the other hand, works such as Les Demoiselles d' Avignon 1907 by Picasso and Corpus Hypercubus - Crucifixion 1954 by Dali, the complex concept of the ForthDimension was first articulated visually to expose knowledge of the concept through painting as a transcendence of the Third-Dimension in space long before mathematicians and physicists could think of the possibility of 4D. Art, therefore, is a structured approach to exposition, knowing and knowledge. In a cognitivist sense, works of art represent the artist's ability to create a structure of forms that are in their relationships analogues to the forms of feeling humans experience and their thought processes. Thus, what the artist can do is to provide a means through which feelings and alternative realities can come to be known. This is why Susanne Langer argues that every art expresses insight into what the artist knows and is a window to his expression to the world a structured insight into the nature of sentience, experiences, and ideologies for the world to know as well [6]. Such knowledge is not expressible in ordinary discourse because they are logically incommensurate, but rather more expressive through a series of complex visual structural manipulations and semiotics. Through such visual manipulation and semiotics, art provides alternative narratives and realities that constitute new perspectives through which we can perceive and experience the world. This knowledge-generating power of art as a paradigm of knowlege is further advanced by Elloit Eisner who in the essay Art and Knowledge 2008 argues that;

The arts address the qualitative nuances of situations...in addressing what is subtle but significant, the arts develop dispositions and habits of mind that reveal to the individual a world he or she may not have noticed but that is there to be seen...Arts produces knowledge through empathic feeling. Through artistically expressive ways art creates such powerful image that as a result, we tend to see our world in terms of it, rather than it in terms of our world...finally, art provides fresh perspective so that our old habits of mind do not dominate our reactions with stock responses. What we seek are new ways with which to perceive and interpret the world, ways that make vivid realities that would otherwise go unknown - art provides that platform [7]. 
Like Kleinbauer, in the extract above Eisner espouses three major ways the arts helps in knowing, making it clear that rather being a thing of superficial aesthetic or utilitarian value, art is rather a way of interpreting and expressing the universe, a way of interrogating/knowing concepts and phenomena, a way of creating new perspectives/approaches to reality; and a way of generating new ideas. It is this aspect of art as a way of generating new knowledge and a mechanism for knowing that is pertinent to this paper. This interrogative and intellectual ethos of artifactuality is what defines contemporary African art-space. In contemporary Africa, there is a new creative paradigm in the arts that involve the manipulation of media to create alternative narratives and knowledge to inform and stir responses from the masses by exposing them to certain phenomena in distinct ways that language cannot express. This new phenomenon is what I refer to as Contemporary Avant-gardism in African Art.

\section{Contemporary African Avant-gardism: Art as Revelation}

The art philosopher Jared Moore opines that art is a form of revelation that reveals a superior knowledge and force beyond the plastic manifestation of reality [8]. Contemporary African art is defined by this philosophy with its plethora of invented visual idioms. The emphasis in contemporary African art-space is on the production of art as a source of knowledge to reveal the existence of a certain adverse phenomenon in Africa not captured in literary or cinematic forms. The origin of this approach to artifactuality is traced to the late 1980s when a new creative consciousness began sweeping across Africa - a new paradigm when the ideologies that underpinned the creation of art changed dramatically from concerns with nationalism/decolonisation, to focus on addressing contemporary issues. Immediate concerns such as political corruption, economic stagnation, cultural destruction and neocolonial tendencies became the preoccupation of artists leading to the invention of new realities defined by contemporaneity and contemporary bohemianism. New Realities in this context refers to the use of art to create alternative viewpoints or narratives that differs from those held in popular culture or influenced by the mass media/ruling class. It also refers to the creation of new ways of understanding a particular phenomenon or concept as an extension of established notions. In Nigeria, the roots of this postcolonial artistic ethos can be traced to the works of Ghana-born, Nigeria-based sculptor El Anatsui who began connecting environmental degradation in African city centres with neo-imperialism and using his found object art forms to draw attention to such environmental-related problematics in the continent [9]. This contemporary creative ethos was at the same time changing the phase of art in Senegal; a new street art that alternate between literary and plastic art emerged that was soon organised into Dakar Biennale. This art engaged with the contemporary, the immediate and urgent concerns of the present - it preened Africa to reveal its present innate state, its aspirations, problems, struggles and advancement. This engagement with the immediacy of Africa as the conceptual and ideological framework for the production of art defines the works of varying artists such as Frederick Bruly Bouabre, El Anatsui, Soly Cisse, 
Abdoulaye Konate, Yinka Shonibare, Dilomprizulike and others. They through art create complex visual dialogues about contemporary Africa and globalism in general.

The visual configurations of works of art produced by Africans in Africa and those in the diaspora reveal a shared consciousness primarily based on shared themes, ideologies, aspirations and subject matter. This shared consciousness borders on the creation of awareness, the production of alternative realities, the creation of new knowledge and ways of knowing in present-day Africa, with the view of revealing hidden truth to instigate societal transformation. Africa is plagued by varying adversities some of which are abominable to describe literarily. News media in Africa are propaganda mechanisms promulgating construed forms of hyperrealism that masks reality to placate those in power and mislead the masses. But through a new avant-gardist ethos in postcolonial African art, this problem has been addressed. Contemporary African artists assuming bohemian status provide alternative narratives to capture actual Africa as a subversive rejection of the romanticised version flaunted in news media patronised by political bigwigs. Their works create new superstructures of realities through a deconstructivist interrogation of Africa to inform, inspire and educate using the art form or art objects as a point of departure in order to enforce change - social, political and cultural. Their works provide deep insights into the following adverse otherwise hidden but promoted concepts in Africa: Excessive Individualism, Hyperconsumerism, and Neo-colonialism.

\section{$5 \quad$ Excessive Individualism}

The most adverse condition in contemporary Africa is the phenomenon of Excessive Individualism. This refers to a condition were nations' wealth and natural resources are colonised by a privileged few, who use such accumulated wealth to manoeuvre power and develop strategies to enslave their fellow citizens under democratic-dictatorship. Most African leaders today emerged from a genealogy of colonial bourgeois class, thus, adopt colonial ideologies of force and subjugation in leading African nations [10]; according to Peter Ekeh "this bourgeois groups influenced colonial Africa and continue to influence post-colonial African politics operating ideologies routed in colonial thinking as weapons and mechanism for legitimating their hold on their own people"[11]. This legacy of colonialism is the main scourge of contemporary Africa, with a majority of Africans been treated like slaves by their fellow Africans, revealing a condition that is far worse than imperial colonialism. It is only through works of art created by contemporary African artists driven by the concept of Afropolitanism that this problem has been uncovered for interrogation. By Afropolitanism I refer to the framing of art informed by political conditions and tailored to expose, interrogate and challenged those conditions to alter various notions of power and bring about societal transformation. From the attainment of independence till date, many African nations have been blown into varying adverse political conditions occasioned by 
corruption, dictatorship, military coup, politically incited violence/skirmishes etc., all of which has inspired a plethora of artistic responses. This expression of political concern in the works of contemporary African artists draws on the subversive powers of art to propagate a bohemian counter-narrative that challenges those in power for stirring uncertainties in Africa and promoting black-on-black colonialism. In South Africa, for example, Brett Murray using a wide range of material produces protest art that lambasts politicians' corruption and abuse of power. He employs satire in his works especially its metaphoric rhetoric, which he draws upon juxtaposing the language and symbols of power figures, twisting them to reveal the lies and greed they mask. He represents politicians as phalluses and his most recent work 'The Spear 2010' (fig. 1) exemplifies his interrogation of the excesses of the political class in a bohemian expression of his denunciation of widespread corruption among ANC leadership.

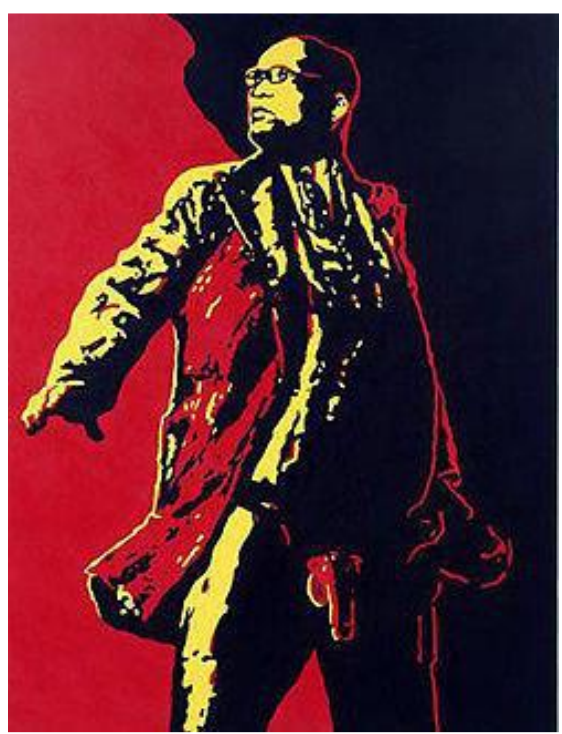

Figure 1. Brett Murray: The Spear 2010

His contemporary Kudzanai Chiurai explores words and images of inner-city Johannesburg to produce subversively bold paintings. His works confront the viewer with explicit messages that mocks African leaders and their trenchant attempts to remain relevant by clinching to power leading to their embrace of dictatorship. His work 'Dying to Be Men 2009', (fig. 2) a series of garish mock portrait photographs of government officials exemplify his use of satirical and mocking portraiture to expose the problematic phenomenon of democratic-dictatorship in Africa. 

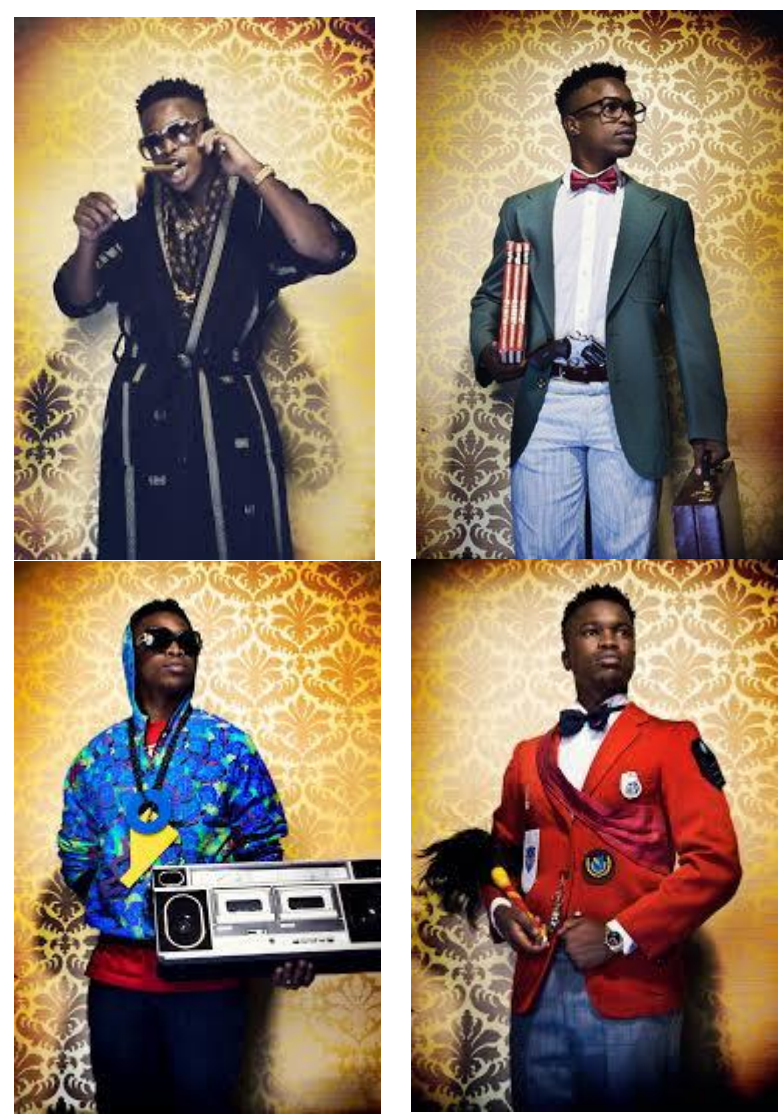

Figure 2. Kudzanai Chiurai: 'Dying to Be Men 2009'

In Ghana, the incompetence of political leaders and its resultant hardship fuelled in parts by corruption and miss-appropriation provides the impetus for this political expressionism as well. Artist Serge Attukwei Clottey creates awareness about the direct links between corruption and economic hardship by using yellow oil gallons to make political statements about the missteps of President Kufuor and his cronies. Exploring the concept of Afrogallonism (fig. 3) he captures present-day Ghana and Africa deformed by the plague of democratic-dictators who have turned the masses into beggars living in penury hence their representation with mundane gallons the contemporary symbol of want and scarcity in Africa. A new generation of Egyptian artists in Cairo have turned to the subversive language of graffiti as a creative mechanism for expressing resistance and revolutionary ideologies against the ruling classes (fig. 4). They use murals to document the crimes, corruptions and incompetence of various regimes, and remind those who take political stands that nothing escapes the eyes and ears of the masses. In defiance of political leaders, they cover their canvasses and walls with portraits of political activists who champion the battles for change and revolution in contemporary Egypt. 


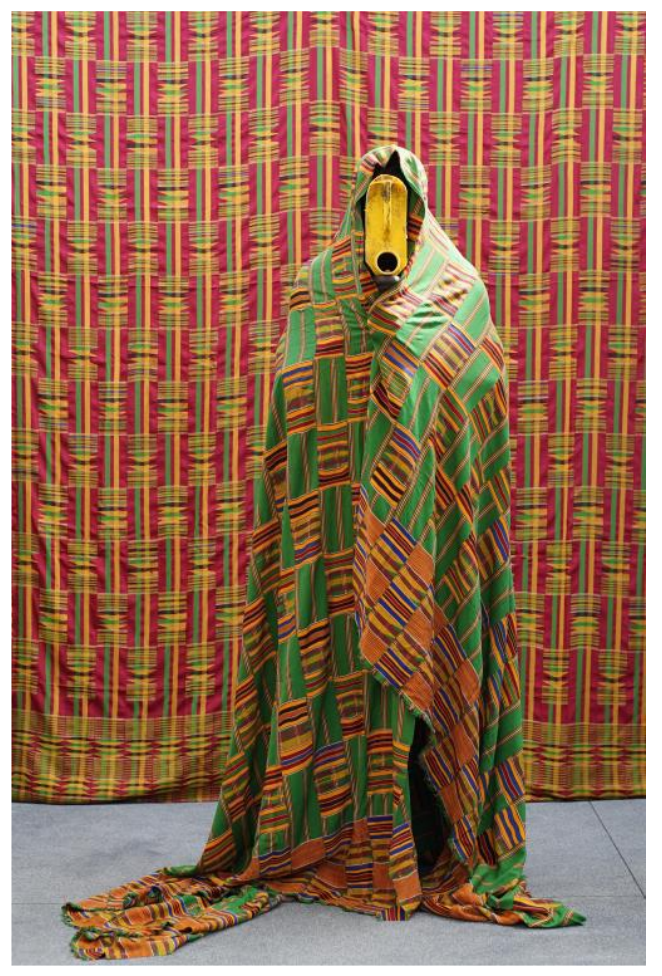

Figure. 3 Attukwei Clottey: Afrogallonism 2010

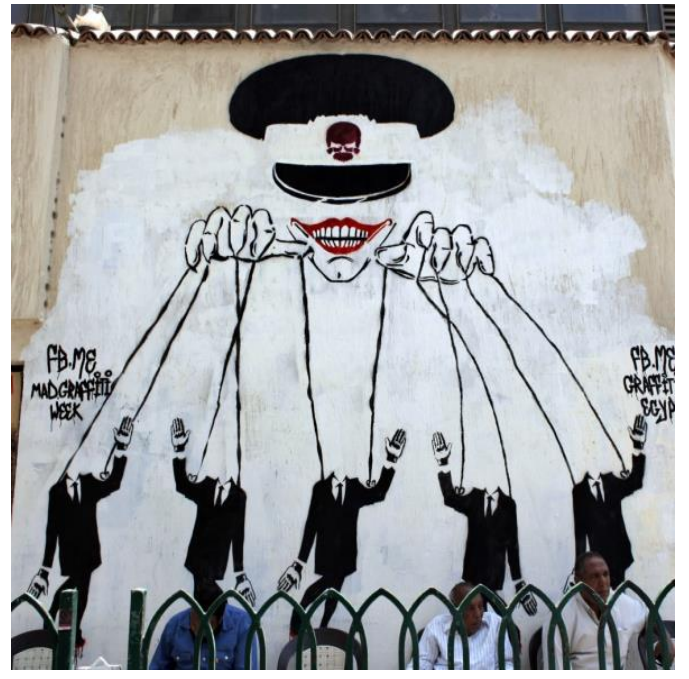

Figure. 4 Egyptian Political Graffiti n.d

The installation Excessive Individualism 2016 (fig 5) by Nigerian artists Clem Akpang is defined by the aforementioned political expressionism. The piece constitutes a revelation about the excesses of politicians and the secrets of democratic-dictatorship which is to suppress, oppress and subjugate the masses in order to differentiate the rulers from the ruled, and the rich from the poor as a parameter of domination/control. The figure of the man towering over the crawling lizards is purposefully exaggerated to be proportionally larger than normal to reveal the greed of corrupt politicians who feed fat from public funds in contrast with the poor masses who are forced into submissive homage because of economic hardship. This socio-political commentary through art as a subversive tool reflects a complex perspective of contemporary African artistic expression in which artists engage with society not to decorate but to challenge, disrupt and transform, to provide an alternative narrative and contemporary reality of African conditions, thus creating new knowledge through artistic formalism or material manipulation. 


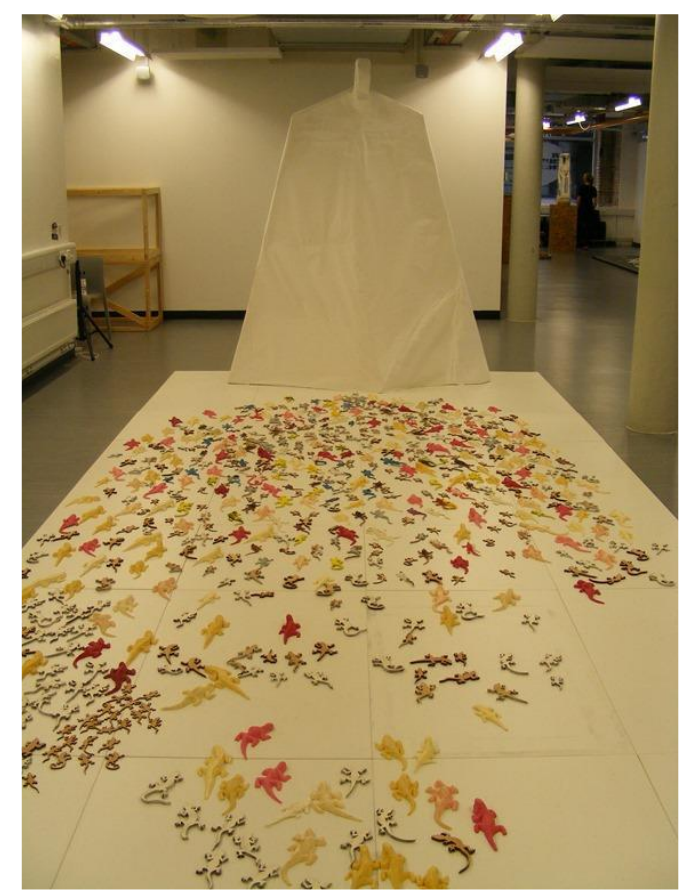

Figure. 5 Clem Akpang: Excessive Individualism 2016

\section{Hyper-consumerism}

Although Africa exists in a contemporary context like the rest of the world, it is still plagued by varying adversities amongst them hyper-consumerism which has transformed Africa into a large tip for waste generated from the West. Against this backdrop, some African artists dedicate efforts to interrogate and engage this urgent problem of their immediate societies, creatively manipulating varying media to address pollution, hyper-consumerism and lack of recycling culture in Africa. Each month about 500 container loads, containing more than 400,000 unwanted computers arrive in Nigeria to be processed. But 75 percent of units shipped to Nigeria cannot be resold; so, they sit on landfills, and children scrabble barefoot on them looking for scraps of copper wire or nails. While the rest of Africans like Nigerians enjoy used Western commodities, contemporary artists use such substandard-used goods as metaphors to create awareness about its resultant environmental/economic adversity in Africa. These artists go beyond documentation of their rapidly changing societies, environment and culture, to assume bohemian positions to facilitate societal transformation by creating alternative narratives to provoke dialogue on the travails of hyper-consumerism.

In Africa, El Anatusi champions the group of artists whose works exposes this menace. His famous work Earth's Skin 2007 (fig 6) - an installation of appropriated aluminium, copper wires, liquor bottle tops, discarded metal sheets etc., is highly political. Through this work, Anatsui draws attention to the damaging impact of hyper-consumerism on Nigerians, society, culture and development. He exposes the problematic of Africa's dependence on Western goods and how 
hyper-consumerism has and is transforming the continent into a pile of waste, thereby destroying its adverse physical landmark.

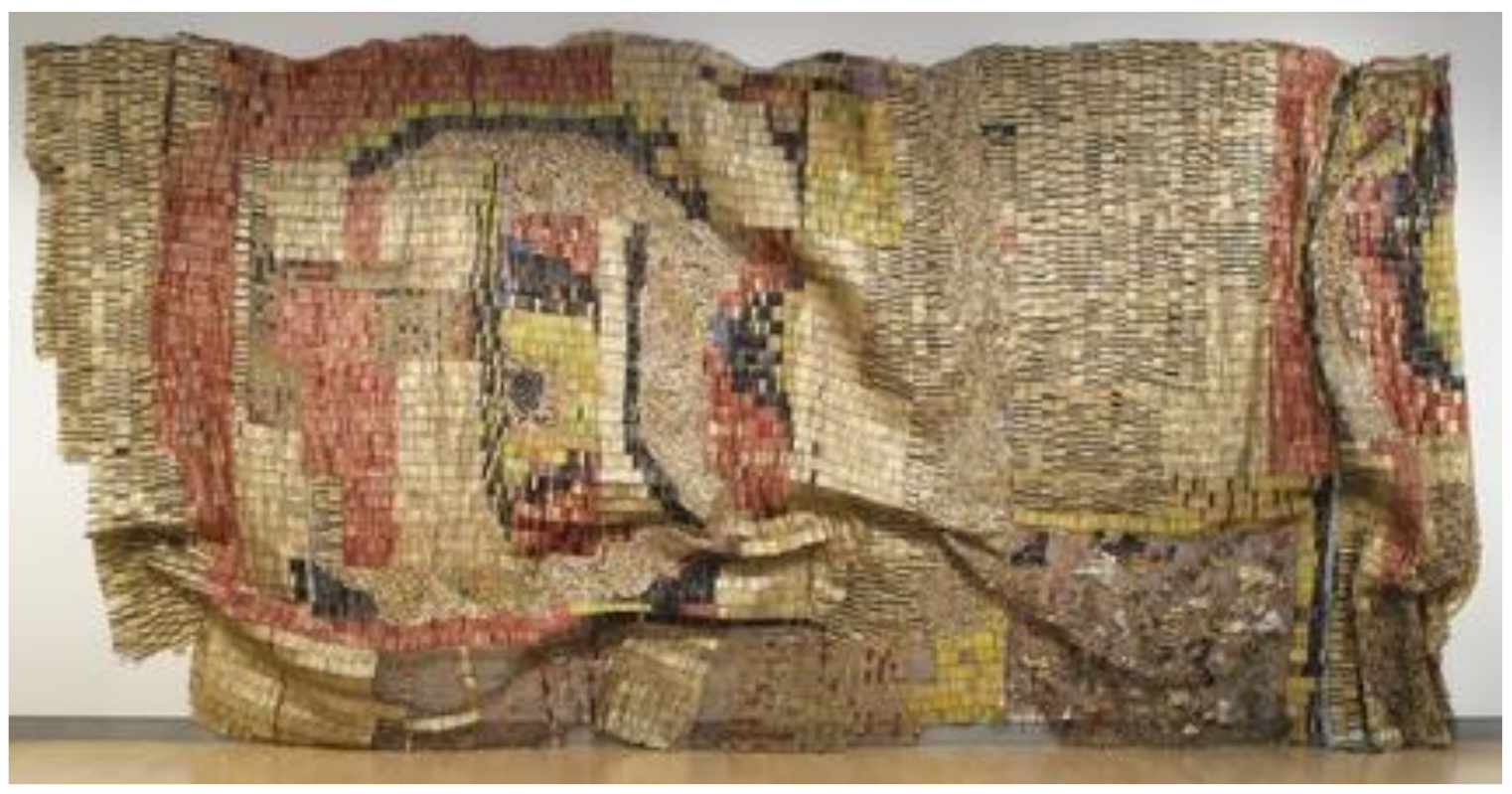

Figure 6. El Anatsui: Earth's Skin 2007

On the other hand, the series of works titled The Hell Copper 2008 (fig 7) by Nyaba Leon Ouedraogo provides another insight into the problem of hyper-consumerism. The striking image of a young man in a field covered in black charcoal suits charging towards a burning basket, with the environment filled with smoke, is a provocative visual discourse exposing the amalgam of environmental challenges in Africa, as well as the impacts of environmental degradation on society, humans, and communities some of which have now been forcefully displaced from their dwellings by illegal activities and the deposition of foreign waste in Africa. The works interrogate an established practice in Ghana involving the burning of old computers that stretch more than 10 kilometres imported from America and Britain, to extract copper from them. Nyaba Leon Ouedraogo exposes the adversities of this contemporary practice to instigate a new dialogue that can save lives and the environment. Another installation Journey out of Africa 2005 (fig 8) by Nigerian artist Dilomprizulike constitutes a visual dialogue that provides different insights into this problem. The piece exposes the crescendo of the menace of hyper-consumerism in which Europe has now saturated Africa with used-goods so much so that the entire space is overtaken. Through this work, the artist draws attention to the displacement of Africans by the uncontrolled dumping of European secondhand goods that forces Africans into migration, and questions the construed ideology of superiority tied to the consumption of foreign products in Africa. 


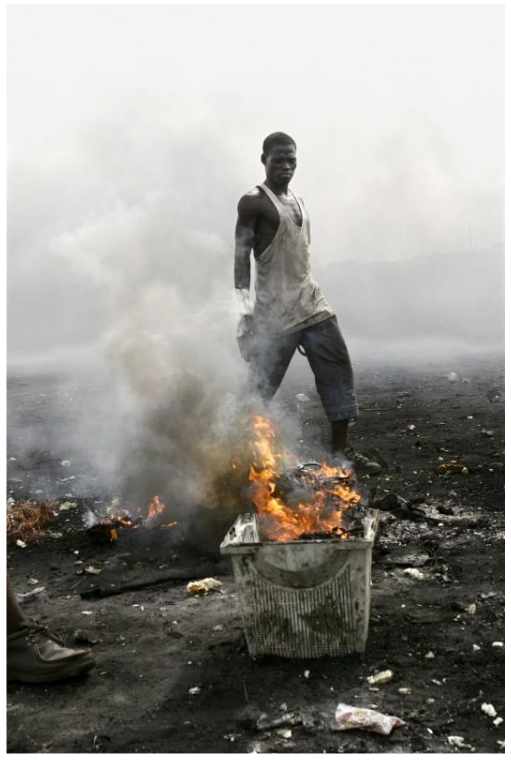

Figure 7. Nyaba Leon Ouedraogo: The Hell Copper 2008

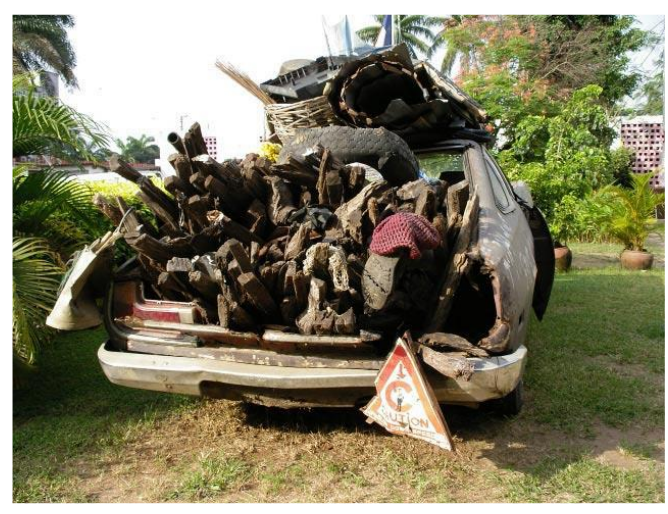

Figure 8. Dilomprizulike: Journey Out of Africa 2005

\section{$7 \quad$ Neo-colonialism}

On the surface, colonialism ended in the 50s and 60s in Africa but the reality is that colonialism has rebranded itself into a new form of neo-colonialism. Economically Africa is still largely controlled by the West and even the constitution of its nation state's national governments is still influenced by western powers such as America, the United Kingdom and France. Contemporary African artists interrogate these concerns and provide perspectives and dialogues through which the legacies of colonialism and the multiple faces of neo-colonialism can be properly understood and tackled. The magnum opus Acid Rain 2005 (fig. 9) by Bright Ugochukwu Eke is a conceptual installation of water in discarded plastic bags, installed hanging from tree branches and gallery roofs as a metaphoric visualisation of the problematised living conditions of the inhabitants of the Niger Delta region. The installation provides an interrogative narrative into contemporary Western oppression, exploitation and manoeuvring of Third World countries and how indigenous peoples are rendered helpless and faceless through oil spillage, acidification of their environment and destruction of their farmlands by multinational companies such as Chevron, Shell, and ExxonMobil etc. Another artwork 'Attachment 2006' (fig. 10) is a conceptual piece that exposes a troubling aspect of neo-colonialism which is voluntary cultural imperialism. The sculptural piece interrogates the obsession with self and the overzealous mimicking of Western cultural values by Africans in their quest for recognition, which adversely results in the loss of the African self. Olu Amoda's exaggeration of the hair, necklaces, earrings and shoulder adornments in this piece is symbolic - it captures the loss of African ideals/cultural identity as a result of excessive irrational copying of Western values, which attaches a false westernised identity on Nigerians. This problem is fuelled in part by the misleading view amongst Africans that the Europeanisation of oneself is a framework for identifying with civility and modernity. Still, in reality, it is merely 
an unwitting destruction of one's cultural identity and value system reflective of a strategy of imperialism in the 1900 s.

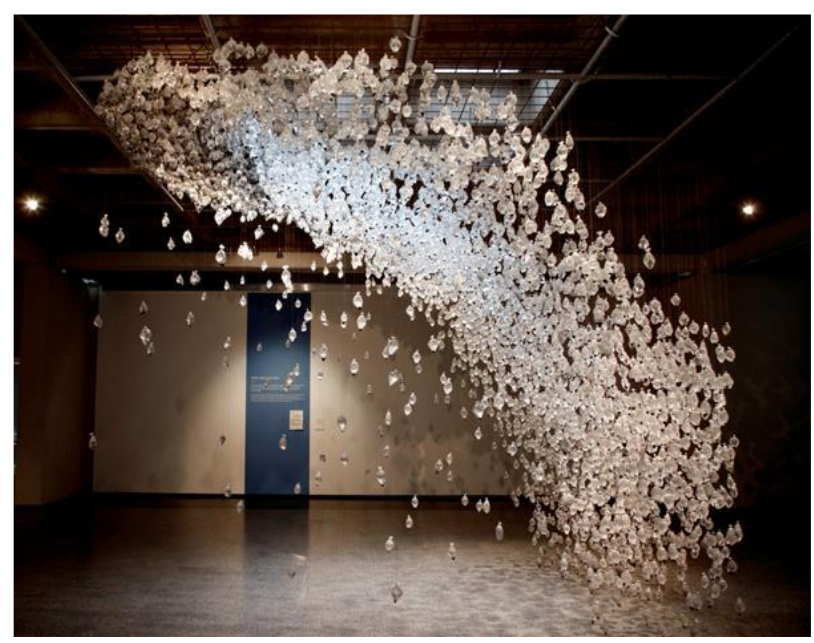

Figure 9. Bright Ugochukwu Eke: Acid Rain 2005

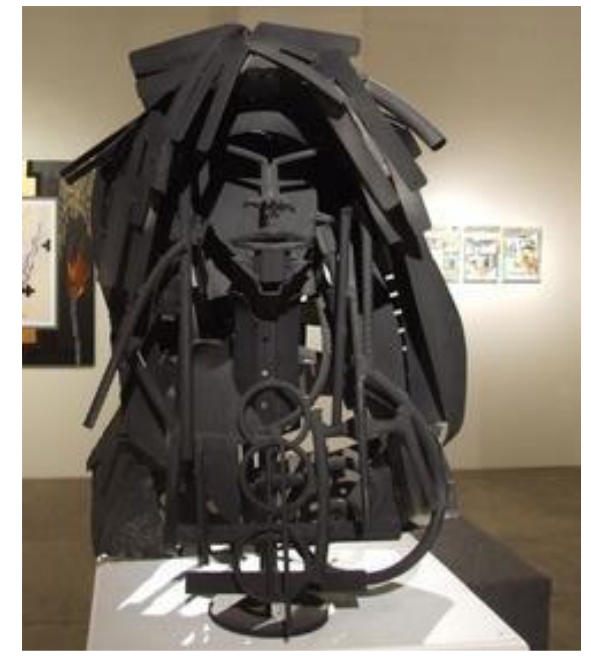

Figure 10. Olu Amoda: Attachment 2006

The aforementioned artists through their works deconstruct the concept of neo-colonialism thus, enabling the masses to become aware of the many faces of neo-colonialism and most importantly the adverse effects of self-imposed cultural imperialism.

\section{Conclusion}

The new approach to artistic expressionism identified in the works of the artists indicates clearly a paradigm shift from concerns with aesthetics, a mere expression of emotions or the popular concept of art-for-arts-sake in the context of academic art, to a realm where art is considered a source of knowledge and a way of knowing through the creation of alternative realities/narratives/perspectives. This is evident in African arts today which thus, suffices to conclude that the arts constitute a fundamental part of being human, providing the tools for serious interaction and interrogation of the world by engaging with questions, formulating ideas, and deepening knowledge. Thus, all art is a way of knowing and a perspective of viewing. Contemporary African artists derive impetus from this philosophy. They have opened up critical dialogues about postcolonial/contemporary existence through art in conceptually expressive ways that language and its relational structures are incapable of attaining. In this sense, through visual dialogue these artists draw viewers into contemplative meaning-making and understanding of society while at the same time defining a subtle form of avant-gardism that is non-radical as the new currency of contemporary African art. 


\section{REFERENCES}

[1] M. Polanyi, M. 'The logic of Tacit Inference', Philosophy, 41(155), 1-18, 1966.

[2] M. Foucault, 'Space, knowledge and Power', The Foucault Reader, pp. 239-256, 1984.

[3] E. Panofsky, Studies in Iconology (p. 141). New York University Press, 1939.

[4] E. W. Kleinbauer, Modern Perspectives in Western Art History: An Anthology of Twentieth-Century Writings on the Visual Arts (Vol. 25). Toronto: University of Toronto Press. 1971

[5] J. Kosinski, Conversations with Jerzy Kosinski. University of Mississippi Press, 1993

[6] S. K. K. Langer, Philosophy in a New Key: a Study in the Symbolism of Reason, Rite, and Art. Harvard: Harvard University Press, 1957.

[7] E. Eisner, 'Art and knowledge', Handbook of the Arts in Qualitative Research, 3-12, 2008

[8] D. J. S. Moore, 'Art as Revelation', Design, 47(3), pp. 3-5. 1945

[9] C. E. Akpang, Contemporary Discourse and The Oblique Narrative of Avant-Gardism in Twentieth-Century Nigerian Art. International Journal of Cultural and Art Studies (IJCAS) Vol. 04, No. 1, 9-22, 2020

[10] S. Diop, 'African Elites and their Post-colonial Legacy: Cultural, Political and Economic Discontent-by Way of Literature', Africa Development, 37(4), pp. 221-235. 2013

[11] P. P. Ekeh, 'Colonialism and the Two Publics in Africa: A Theoretical Statement', Comparative Studies in Society and History, 17(1), 91-112, 1975. 